\title{
Role Of Urban Farmer Group's Leader As Opinion Leader On Utilizing Urban Yard In Yogyakarta City
}

\author{
Agatha Zenobia Rachman and Aris Slamet Widodo* \\ Department of Agribusiness, Faculty of Agriculture, University of Muhammadiyah Yogyakarta, \\ Indonesia
}

\begin{abstract}
One of urban agriculture activities in Yogyakarta City was utilizing yard through farmer groups coordinated by group's leader as opinion leader. This study aims to i) Describe farmer group's activities and management on utilizing urban-yard in Yogyakarta City, ii) Determine role of group's leader in utilizing urban-yard in Yogyakarta City, iii) Analyze factors related to member's perceptions of the role of group's leader in utilizing urban-yard in Yogyakarta City. There were 48 samples selected by multistage random sampling. Data were analyzed by descriptive analysis to describe activities and management of farmer groups, table analysis to determine role of group's leader, and rank spearman correlation analysis to analyze factors related to member's perceptions of role of group's leader. The result indicated that urban farmer group had several activities. On management, urban farmer groups didn't have comprehensive organizational structure and administrative records. The instructive, consultative, and participatory roles of group's leader can be categorized very good. Meanwhile liaison role was categorized good. Factor that had significant correlation to member's perceptions of the role of group's leader was role of agricultural extention.
\end{abstract}

\section{Introduction}

Agriculture is usually identical with rural areas because of availability of larger agricultural land, unlike in urban areas. However, agricultural activities are currently not only carried out by rural communities, but also people in urban areas. One of urban agriculture activities was utilizing yard with the aim of optimizing land use. Yards that can be used for urban agricultural-based activities are unused urban land. However, urban areas are identical with limited land so that yards that can be used including household yards. Urban-yards are utilized by doing cultivation of various type of plants that can be consumed, mantain food security, and increase the income [1] .There are inovations in cultivating plants in limited area such as hydroponics, verticulture, and aquaponics.

Optimization of urban-yard utilization activities can be supported by extincence of farmer groups. Based on the data from Departement of Agricultural and Food of

* Corresponding author: aris.sw@umy.ac.id 
Yogyakarta City[2], the number of farmer groups in Yogyakarta City is 177 groups. Farmer groups are formed so that agricultural activites can run optimally and efficiently. Farmer groups are coordinated by group's leader. Group's leader can be an opinion leader because a leader can motivate, guide, and give information to members. An opinion leader are usually have strong characteristics, good at communication, innovative, knowledgeable, and also has ability to influence others[3].

The city of Yogyakarta is one of cities that has urban-yard utilization activities through 'Kampung Sayur' program as an effort to optimize the use of urban agriculture-based yards and also increase consumption of nutritious, balanced, and safe food. The program is run by farmer groups spread in 14 sub-districts in Yogyakarta City. There are two kinds of farmer groups in Yogyakarta City, there are Kelompok Tani Dewasa (KTD) and Kelompok Wanita Tani (KWT). According to the name, the different between both of them are from the gender of the members. KTD is 'adult farmer group' whose members are adult men and women, while KWT is 'women farmer group' whose members are only women. Limited land and characteristics of urban communities who usually do not have much time and knowledge related to agriculture caused the role of urban farmer group's leader as an opinion leader is needed in providing direction, knowledge, and motivation so that group activities can run well. This study aims to i) Describe farmer group's activities and management on utilizing urban-yard in Yogyakarta City, ii) Determine role of group's leader in utilizing urban-yard in Yogyakarta City, iii) Analyze factors related to member's perceptions of the role of group's leader in utilizing urban-yard in Yogyakarta City.

\section{Methodology}

The location for this study was determined purposively in Yogyakarta City, Special Region of Yogyakarta. Meanwhile, the sample of this study were selected by Multistage Random Sampling. There were three sub-districts used in this study, they are Danurejan District, Kraton District, and Mantrijeron District. From that three sub-district, two farmer groups were selected in each sub-district so that there were six farmer groups selected. The selection of the groups was based on their activities on participating in 'Kampung sayur' Program which was accordance with the rule of Department of Agriculture and Food of Yogyakarta City, and had innovations in agricultural technology, information, and product proccessing. Afterwards, 8 group's members were taken randomly from each farmer group so that the sample consisted of 48 members.

Table 1. Sampling based on Multistage Sample

\begin{tabular}{|c|c|c|c|c|}
\hline No & District & Farmer Group & $\begin{array}{c}\text { Number of } \\
\text { members }\end{array}$ & $\begin{array}{c}\text { Number of } \\
\text { Samples }\end{array}$ \\
\hline \multirow{2}{*}{1} & \multirow{2}{*}{ Danurejan } & Gemah Ripah & 25 & 8 \\
\hline & & Amanah & 20 & 8 \\
\hline \multirow{2}{*}{2} & \multirow{2}{*}{ Kraton } & Naga Asri & 20 & 8 \\
\hline & & L. M. Binangun & 20 & 8 \\
\hline \multirow{2}{*}{3} & \multirow{2}{*}{ Mantrijeron } & Surya Hijau & 20 & 8 \\
\hline & & Mina Julantoro & 15 & 8 \\
\hline \multicolumn{3}{|c|}{ Total } & 120 & 48 \\
\hline
\end{tabular}

Primary data of this study was the profile of respondents, farmer group's activities and management, and member's perceptions of the role of farmer group's leader in utilizing urban-yard. Meanwhile, secondary data in this study was obtained from Departement of 
Agriculture and Food of Yogyakarta City in the form of number and identity of farmer groups in Yogyakarta City which includes the name of the group, line of business, commodity, group address, year of establishment, and number of members.

Data analysis technique in this study was descriptive analysis that is used to describe farmer groups' activities and management on urban-yard utilization in Yogyakarta City. The data analyzed were primary data obtained from interviews with group's leader and also observation to urban farmer groups. Furthermore, table analysis by scoring technique was used to explain the role of the group's leader as an opinion leader on four indicators, such as instructive, consultative, participatory, and liaison based on members' perception. Meanwhile, Rank Spearman Correlation Analysis was used to analyzed member's perceptions of the role of group's leader in utilizing urban-yard. The analysis results can be categorized as follows:

Table 2. The Category of Strength of Correlation Values

\begin{tabular}{|l|c|}
\hline \multicolumn{1}{|c|}{ Category } & Strength of Correlation Values \\
\hline Very Week & $0.00-0.199$ \\
\hline Week & $0.20-0.399$ \\
\hline Medium & $0.40-0.599$ \\
\hline Strong & $0.60-0.799$ \\
\hline Very Strong & $0.80-1.000$ \\
\hline
\end{tabular}

\section{Result and Discussion}

\subsection{Respondent Profile}

Respondent Profile including age, education, and farming experience. Age is indicated in years, education in level of education, meanwhile farming experience is indicated by the length of farming experience in years.

Table 3. Respondent Profile

\begin{tabular}{|c|l|l|c|}
\hline No & Description & Unit & Average \\
\hline 1 & Age & Year & $42-54$ \\
\hline 2 & Education & Level of Education & Finished Senior High School \\
\hline 3 & Farming Experience & Year & $0-7$ \\
\hline
\end{tabular}

The data above shows that the members of farmer groups are dominated by members in the age range $42-54$ years. The last educational level that is mostly taken by members of farmer groups in Yogyakarta is Senior High School (SMA) with 31 members. The high level of education of members is supported by the existence of school facilities in Yogyakarta. Most members have farming experience for $0-7$ years as many as 42 members. This is because most people in urban areas do not have agricultural background that caused lack of experience in farming. However, there is one member who have experience more than 32 years because of her job as plants' seller.

\subsection{Farmer Group Activities in Utilizing Urban Yards}

Urban-yard utilization activities which created by the goverment through farmer groups are 'Kampung Sayur'. 'Kampung Sayur' is a village-based urban environtment concept that utilizes yards intensively as source of foods by planting various types of vegetables 
according to the needs of local community. In the implementation of this program, infrastructure facilities are needeed such as seed house, vegetable garden, and vegetable aisles.

Several farmer groups, namely KTD Gemah Ripah, KWT Amanah, and KWT Surya Hijau are farmer groups that have appropriate facilities and infrastructure in the form of seed houses, vegetable gardens, and vegetable aisles. While KTD Lumbung Mataraman Binangun, KWT Naga Asri, and KWT Mina Julantoro focused on the use of urban yards, both in group gardens and in the yards of each member's house. They also did not have vegetable 'aisles'.

The next activity is plant cultivation. Plant cultivation is the main activity carried out by farmer groups in the city of Yogyakarta. Due to limited land, most of planting procedures are carried out by using pots or polybags. The types of plants cultivated are very diverse, such as vegetable plants, fruit plants, food plants, medicinal plants, to ornamental plants. Vegetable plants that are widely cultivated are kale and chilies because most people like and used them as ingredients for food. Kale plants are widely cultivated together with catfish cultivation through cultivation in buckets (budidamber) in accordance with government programs. Fruit plants are mostly propagated by cutting method because it is easy to do, does not take a long time until harvesting, and does not require large area so that fruit plants can be cultivated in pots.

Ginger, as medicinal plants are widely cultivated by farmer groups because of Tanam Herbal Bejo (THB) Program in 2019 supported by PT. Bintang Toedjoe. The program invites farmer groups in Yogyakarta to cultivate ginger. While the ornamental plants are widely cultivated are orchids. KWT Surya Hijau is an urban farmer group that has a spesific garden to cultivate various types of orchids. Meanwhile, other farmer groups cultivate ornamental plants as pest diversion.

Processing of agricultural products is activity that functions to increase the economic value of a certain material so that it can help improve the economy of group and also group members. One of the farmer groups that process agricultural products is KWT Surya Hijau. In this group, telang flower is used as an agricultural product which processed as syrup

The next activity is marketing. KTD Gemah Ripah and KWT Amanah in Danurejan are groups that active in operating social media such as Facebook and Youtube, so that all the promotional activities carried out by using social media. While marketing activities in KWT Naga Asri are the responsibility of each member because cultivation activities are carried out individually. In addition, KWT Naga Asri is also a member of the Association of Vegetable Farmers in the City of Yogyakarta (Sepur Kota) together with several farmer groups including KTD Gemah Ripah, KWT Amanah, and KWT Surya Hijau which carry out marketing activities in alun - alun kidul every Sunday morning. Marketing activities at KWT Surya Hijau are carried out by offering to the local community first and telang syrup product is usually promoted through exhibition activities. While at KWT Mina Julantoro, marketing activities are more focused on the fisheries sector in the form of agro-tourism.

The exhibition activity which is routinely held every year by Department of Agriculture and Food of Yogyakarta City is Lumbung Mataraman Expo. In 2020, Lumbung Mataraman Expo was held in the Court of Department of Agriculture and Food of Yogyakarta and was attended by farmer groups assisted by Lumbung Mataraman including KWT Surya Hijau. In addition to exhibitions, the government usually also holds competitions at certain events so that farmer groups are able to improve their achievements in utilizing urban yards, such as KTD Gemah Ripah who won first place in 'Kampung Sayur' competition in Yogyakarta City in 2019, and KWT Surya Hijau who won the 'Hatinya PKK' competition in 2017.

Optimizing the performance of farmer groups is supported by training activities. Training for farmer groups is carried out through Technical Guidance (Bimtek) held by 
Department of Agriculture and Food of Yogyakarta City. The training activities from the government will be adjusted to programs planned by the government. For example, there is training on cendol catfish cultivation for the Cultivation in Bucket (Budidamber) program. Training is also done through the role of agricultural extension worker in providing education related to the cultivation of plants to members of farmer groups. However, several farmer groups such as KWT Naga Asri, KWT Surya Hijau, and KTD Gemah Ripah have group's leaders who also act as self-help agricultural extension worker so that they are able to provide individual training to the group. This is an advantage for the group because the training can be adapted to the circumstances and conditions of the group so that the results of the training can be directly applied by members.

\subsection{Farmer Group Management}

The Farmers Group in this study is a group that has been officially registered by the Department of Agriculture and Food of Yogyakarta City. The formation of farmer groups is an idea that aims to optimize urban-yard while maintaining ecosystems and food security by utilizing urban-yard, the agricultural products can also be utilized by the community. Structurally, most farmer groups consist of a group leader, treasurer, and members. The election of farmer group's leader is elected directly or by voting based on the position or knowledge possessed by a person. On average, urban farmer groups do not have comprehensive organizational structure and administrative records. It is indicated by the absence of modules related to group profiles. In urban farmer groups, the rights and obligations of members are also not attached in writing.

Farmer groups have activities that are social and not profit-oriented, namely pickets and regular member meetings. The selection of picket groups is carried out randomly and equally for all members to maintain and taking care for plants, especially for farmer groups who have group gardens. Picket activities are carried out every day including planting, watering, adding planting media, controlling pests, and other treatments. Every month, farmer groups have regular meetings which are attended by all group members. The meetings are held once a month with a different date in each group. Things that are carried out in group meetings include sharing information, evaluations, discussions related to group problems, and determining plants to be planted by group based on the types of plants that are preferred and used by members or the community.

\subsection{Role of Farmer Group's Leader}

Role is a dynamic aspect of position or status[4]. A leader as an opinion leader usually has a character that is different or superior to other members[5]. So that the role of opinion leader becomes important and influences the sustainability and development of a group.

A leader acts as a liaison between a company or group and external parties. Companies or groups that collaborate or partner with other parties will develop faster. Meanwhile, based on the main function of leadership, a leader has the following roles:

- Instructive, the leader has a role in giving instructions and directions to the member so that the work can be carried out effectively

- Consultative, the leader has a role to activing members that aim to get ideas, feedback, and opinions from members as material for improvement or perfection of the decisions made.

- Participative, the leader carries out a participatory role by motivating members to participate actively in carrying out activities in the group. 
Table 4. Role of Group's Leader

\begin{tabular}{|c|l|c|c|}
\hline No. & \multicolumn{1}{|c|}{ Indicator } & Average & Category \\
\hline 1 & Instructive Role & 3.83 & Very Good \\
\hline 2 & Consultative Role & 3.81 & Very Good \\
\hline 3 & Participatory Role & 3.74 & Very Good \\
\hline 4 & Liaison Role & 3.05 & Good \\
\hline \multicolumn{2}{|c|}{ Total Average } & 3.61 & Good \\
\hline
\end{tabular}

Note:

Bad $\quad=1-2.33$

Good $\quad=2.34-3.66$

Very Good $\quad=3.67-5$

Based on the results of this study show that the role of farmer group's leader as an opinion leader as a whole can be categorized as good with an average score of 3.61. This can be showed that the leader of the farmer group in Yogyakarta City has a fairly good role in carrying out its role in the utilization of urban-yards. The data above also shown that instructive, consultative, and participatory role of farmer group's leader can be considered 'very good'. While the liaison role can be categorized as 'good'.

Instructive role of the farmer grorup leaders has the highest average score among other, which is 3.83. The characteristic of the average people in urban area who did not have a background in agriculture makes the instructions or directions from the leader are very helpful for members in carrying out urban yard utilization. The instructions and direction from leader can be deliver as an explanation of group activities' direction or instructions on plant cultivation activities such as the time for watering plants or giving pesticides to plants that are attacked by pests. In addition, the leader also has a role in providing direction regarding problems related to plant cultivation activities faced by members. In line with the previous research which identified that opinion leaders has a role as critical liaison who provide solutions to difficult issues faced by members[6].

The average score of consultative role is 3.81 or it can be categorized as 'very good'. The consultative role can be seen from discussion activities that are usually carried out during regular meeting to discuss things related to group activities or problems faced by both of members and groups. In discussion activities, the leader gives members the opportunity to conveyy ideas or opinions related to groups that are needed as part of developing the groups. Supporting this condition, Bahfiarti [7] revelaed that one of the characteristics of an opinion leader is open to ideas or oppinions submitted by group members.

Urban Agriculture defined as environmental and social service providers, access to fresh and better food, urbanization and redefined as an activity that produces processes, and markets food, fuel, and other outputs $[8,9,10]$. Participation of community members in urban farming is higly related to the level of awareness of the benefits of the activity. To be successful, it is important that participation of members is kept continuous in the implementation of urban farming[11]. Based on members perception, the participatory role of leader are shown from giving motivation to members to be active in group, cultivate urban yard, increase the production yields, and develop the group's potential. This is also in accordance with the research results of Metalisa, Saleh and Tjitropranoto[12] which revealed that group's leaders play a role in motivating members on doing activities.

Meanwhile, the liaison role of the group's leader is in 'good' category with the average score 3.05. Based on the results of data analysis and conditions in the field, the liaison role of group's leaders in connecting groups with several institutions is less than optimal. The 
less than optimal role of leader as a liaison is caused by the condition of the group that currently does not need certain parties or institutions as partners.

\subsection{Factors Related to Members' Perceptions Regarding the Role of the Leader}

Correlation analysis between factors such as age, gender, education, farming experience, and the role of agricultural extension worker as a motivator, facilitator, educator, and communicator with members' perceptions regarding the role of farmer group's leader can be analyzed by Rank Spearman Correlation Analysis which was performed using Statistical Package for the Social Science (SPSS), version 16.0.

Table 5. Result of Rank Spearman Correlation Analysis

\begin{tabular}{|c|c|c|c|c|c|}
\hline Criteria & Instructive & Consultative & Participatory & Liaison & $\begin{array}{l}\text { Leader's } \\
\text { Role }\end{array}$ \\
\hline \multicolumn{6}{|l|}{ Age } \\
\hline Rs & -.008 & .002 & -.106 & .042 & -.068 \\
\hline Sig & .957 & .988 & .471 & .775 & .644 \\
\hline \multicolumn{6}{|l|}{ Education } \\
\hline Rs & .037 & .034 & -.058 & -.145 & -.027 \\
\hline Sig & .800 & .820 & .697 & .326 & .858 \\
\hline \multicolumn{6}{|l|}{ Farming Experience } \\
\hline Rs & .166 & .112 & -.050 & .049 & .056 \\
\hline Sig & .260 & .450 & .737 & .742 & .704 \\
\hline \multicolumn{6}{|l|}{$\begin{array}{l}\text { The Role of } \\
\text { Agricultural Extension } \\
\text { as Motivator }\end{array}$} \\
\hline Rs & .427 & .464 & .668 & .232 & .551 \\
\hline Sig & $.002 *$ & $.001 *$ & $.000^{*}$ & .113 & $.000 *$ \\
\hline \multicolumn{6}{|l|}{$\begin{array}{l}\text { The Role of } \\
\text { Agricultural Extension } \\
\text { as Facilitator }\end{array}$} \\
\hline Rs & .523 & .525 & .645 & .664 & .689 \\
\hline Sig & $.000^{*}$ & $.000^{*}$ & $.000^{*}$ & $.000^{*}$ & $.000 *$ \\
\hline \multicolumn{6}{|l|}{$\begin{array}{l}\text { The Role of } \\
\text { Agricultural Extension } \\
\text { as Educator }\end{array}$} \\
\hline Rs & .636 & .701 & .722 & .565 & .756 \\
\hline Sig & $.000^{*}$ & $.000^{*}$ & $.000^{*}$ & $.001 *$ & $.000 *$ \\
\hline \multicolumn{6}{|l|}{$\begin{array}{l}\text { The Role of } \\
\text { Agricultural Extension } \\
\text { as Communicator }\end{array}$} \\
\hline Rs & .629 & .659 & .450 & .101 & .543 \\
\hline Sig & $.000^{*}$ & $.000^{*}$ & $.001 *$ & .496 & $.000 *$ \\
\hline
\end{tabular}

Note: *) Siginificant on $\alpha=1 \%$

**) Siginificant on $\alpha=5 \%$

***) Siginificant on $\alpha=10 \%$

Based on the results of the analysis above, it can be identified that the factors of age, education, and farming experience have no significant correlation to members' perceptions regarding the role of farmer group's leaders in utilizing of urban-yards. This means that the perception of members regarding the role of the farmer group's leader is not related to 
factors that come from internal sources such as age, education, and farming experience. It is because the members see the role of the group's leader based on the group leader's actions in giving instructions, discussing, mobilizing members, and establishing partnerships that can facilitate members in carrying out urban agricultural activities.

Meanwhile, the role of the instructor as a motivator, facilitator, educator, and communicator has a significant relationship with an error rate of $1 \%$. This is also similar to the results of research from Satria et al[13] which revealed that the role of the leader was positively influenced by Agricultural Extension Officers (PPL). The role of the agricultural extension worker is able to correlate with members' perceptions of the role of farmer group's leader in utilizing urban-yards. Based on the condition in the field, the role of agricultural extension worker on communicating, providing direction and information, and motivating members can be a great example for the leader in applying these roles to the members. So that the role of the agricultural extension worker is correlated to the perception of members of farmer group's leader role in utilizing urban-yards.

However, there are several roles of agricultural extension workers that have no significant correlation with the role of the farmer group's leader. The correlation between agricultural extension worker as a motivator and the role of group's leader as liaison is not significant because the motivation given is more on the utilization of urban agricultural yard activities.

In addition, the correlation between the role of agricultural extension worker as a communicator is not significant to the role of group's leader as liaison. It is because the infromation that the agricultural extension worker deliver to the group is about the program related to urban yard utilization or information from the goverment. This result also related to the past research[14] that mention the agricultural extension worker has a role as communicator on upstream subsystem and on farm subsystem.

\section{Conclusion}

Yogyakarta City has an urban-yard utilization program named 'Kampung Sayur' which is run by farmer groups in the city of Yogyakarta. In that program, farmer groups have activities such as urban-yard utilization, plant cultivation, processing agricultural product, marketing, exhibitions, and training. On management, urban farmer groups do not have comprehensive organizational structure and administrative records. The role of farmer group's leader as an opinion leader in the utilization of urban-yards is indicated from four indicators. Instructive, consultative, and participatory roles can be categorized very well. Meanwhile, the liaison role is categorized as good. Overall the role of the farmer group's leader as an opinion leader in the utilization of urban-yards can be categorized as good. Based on Rank Spearman Correlation Analysis, it is known that age, education, and farming experience factors have no significant correlation with members' perceptions regarding the role of group's leader. Meanwhile, the role of agricultural extension worker has significant relationship with members' perceptions regarding the role of farmer group's leader.

The condition in the field indicate that the role of farmer group's leader as liaison in establishing partnership less than optimal, so it is suggested that the group should increase the role group's leader as liaison to establish relationship with various external parties who have capability of supporting groups on utilizing urban agricultural yard. 


\section{References}

1. O. J. Ovharhe, "Appraisal of backyard farming among households: implications for rural development and food security in Nigeria," Asian J. Agric. Rural Dev. 10, 1 pp. 160-170, (2020)

2. Departement of agricultural and food of yogyakarta city, "Data of Urban Farmer Group in Yogyakarta City" (2020).

3. R. H. Nunes, J. B. Ferreira, A. S. de Freitas, and F. L. Ramos, "The effects of social media opinion leaders' recommendations on followers' intention to buy," Rev. Bras. Gest. Negocios 20, 1, 57-73 (2018)

4. M. Rahmanita, "Peran penyuluh pertanian lapangan (PPL) sebagai opinion leader dalam meningkatkan hasil tani kelompok tani di giri rejo kelurahan lempake samarinda,” eJournal Ilmu Komun., 4, 2, 460-472 (2016)

5. S. Oktarina and S. Sarwoprasodjo, "Opinion Leader Political Communication Strategy in Diffusion Development Program and Development of Local Institutions in Rural" MetaCommunication;Journal Commun. Stud. 3, 1, 78-90 (2018)

6. J. Rumble, K. Lamm, H. Carter, and A. Lamm, "Agricultural Opinion Leader Communication Channel Preferences: An Empirical Analysis of Participants of Agricultural and Natural Resource Leadership Development Programs," J. Agric. Educ. 57,1, 91-105(2016)

7. T. Bahfiarti, "Peran key farmer sebagai opinion leader melalui komunikasi kelompok dalam penerimaan inovasi petani di sentra pertanaman kakao sulawesi selatan" $J$. Pekommas, 1, 2, 197-206 (2016)

8. C. Dimitri, L. Oberholtzer, and A. Pressman, "Urban agriculture: connecting producers with consumers," Br. Food J. 118, 3, 603-617 (2016)

9. I. Opitz, K. Specht, R. Berges, R. Siebert, and A. Piorr, "Toward sustainability: Novelties, areas of learning and innovation in urban agriculture," Sustain., 8, 4, 1-18 (2016).

10. R. Islam and C. Siwar, "The analysis of urban agriculture development in Malaysia," Adv. Environ. Biol. 6, 3, 1068-1078 (2012)

11. [N. H. B. Yusoff, M. R. M. Hussain, and I. Tukiman, "Roles of community towards urban farming activities," Plan. Malaysia, 15, 1, 271-278 (2017)

12. R. Metalisa, A. Saleh, and P. Tjitropranoto, "Peran ketua kelompok wanita tani dalam pemanfaatan lahan pekarangan yang berkelanjutan" J. Penyul., 10, 2 (2015)

13. E. A. Satria P, R. Witjaksono, and H. Harsoyo, "Peran ketua kelompok tani dalam adopsi teknologi budidaya bawang merah di lahan pasir pantai kecamatan sanden kabupaten bantul" Agro Ekon. 27, 2, 150-164 (2017)

14. R. Yulida, Rosnita, Y. Andriani, and M. Ikhwan, "Communication analysis of rubber farmersin riau province, indonesia" Int. J. Media Commun. Researc, 2, 1, 23-36 (2021) 